\title{
AKTUALISASI PIIL PESENGGIRI SEBAGAI FALSAFAH HIDUP MAHASISWA LAMPUNG DI TANAH RANTAU
}

\author{
Camelia Arni Minandar \\ SMA Negeri 7 Bandung \\ Email: cameliawr@gmail.com
}

\begin{abstract}
Abstrak
Piil pesenggiri adalah salah satu kearifan lokal yang berasal dari daerah Lampung. Piil pesenggiri ini merupakan falsafah hidup bagi orang Lampung. Dengan kata lain, piil pesenggiri merupakan nilai dan norma yang mengatur tata hidup masyarakat Lampung sebagai makhluk sosial. Piil pesenggiri ini dijadikan sebagai landasan dalam berpikir, bertindak dan juga berperilaku oleh masyarakat Lampung dimana pun mereka berada. Terdapat 4 aspek dalam piil pesenggiri, tetapi dalam penelitian ini hanya difokuskan pada 3 aspek saja, yaitu nemui nyimah (ramah tamah dalam menyambut tamu), nengah nyappur (mudah berbaur dalam masyarakat), dan sakai sambayan (tolong menolong dan bergotong royong). Penelitian ini bertujuan untuk mengetahui bagaimana mahasiswa Lampung dalam menerapkan piil pesenggiri sebagai falsafah hidup selama ia berada di tanah rantau. Penelitian ini menggunakan metode deskriptif, karena penelitian ini bermaksud untuk mendeskripsikan, menganalisis, dan kemudian akan mengambil suatu generalisasi tentang penerapan piil pesenggiri sebagai falsafah hidup mahasiswa Lampung yang sedang menempuh pendidikan di Kota Bandung. Hasil penelitian mengungkapkan bahwa penerapan piil pesenggiri selama mahasiswa Lampung berada di tanah rantau mengalami hambatan. Hambatan ini dirasakan ketika mahasiswa Lampung menerapkan piil pesenggiri ini di lingkungan sekitar tempat tinggal di tanah rantau. Hal tersebut terjadi karena adanya faktor internal yang berasal dari dalam diri mahasiswa Lampung itu sendiri, serta faktor eksternal yang berasal dari luar diri mahasiswa Lampung tersebut. Dari adanya hambatan tersebut, terdapat beberapa upaya yang dilakukan oleh mahasiswa Lampung untuk mengatasi hambatan dalam menerapkan piil pesenggiri di lingkungan sekitar tempat tinggal selama berada di tanah rantau.

Kata kunci: $\quad$ Falsafah Hidup, Kearifan Lokal, Piil Pesenggiri
\end{abstract}

\section{PENDAHULUAN}

Indonesia dikenal dengan budayanya yang beragam. Keberagaman budaya yang di Indonesia terlihat dari banyaknya terdapat suku-suku masyarakat yang ada di Indonesia. Suku yang beragam tersebut masing-masing memiliki bahasa, tarian atau juga kesenian yang berbedabeda pula. Keberagaman inilah yang membuat Indonesia menjadi salah satu negara yang banyak diminati oleh wisatawan asing dari berbagai negara karena sangat jarang dengan budayanya yang sangat beragam, tetapi masyarakatnya dapat hidup tentram dan saling berdampingan.

Setiap suku yang ada di Indonesia biasanya memiliki falsafah hidup yang disepakati dan dilaksanakan oleh masyarakatnya. Falsafah tersebut digunakan sebagai pedoman, pandangan hidup dan dijadikan sebagai tuntunan masyarakatnya dalam menjalani kehidupan bemasyarakat. Agar suatu kelompok masyarakat memiliki batasan-batasan atau arahan-arahan supaya terciptanya keselarasan dalam menjalani kehidupan dalam masyarakat. Falsafah hidup yang dianut oleh masyarakat di Indonesia, biasanya akan berbeda pada tiap kelompok masyarakatnya. Hal tersebut dikarenakan falsafah hidup yang dianut dan dijalani oleh masyarakat, harus disesuaikan dengan kebutuhan dan keadaan masyarakat atau kondisi sosial yang berbeda-beda pada tiap kelompoknya.

Salah satu falsafah hidup yang ada di dalam kelompok masyarakat di Indonesia adalah falsafah hidup yang berada di daerah Lampung. Lampung yang merupakan salah satu Provinsi yang memiliki banyak sekali pendatang dari berbagai daerah di Indonesia memiliki falsafah hidup yang dianut atau dijalani oleh masyarakatnya hingga saat ini. Falsafah hidup tersebut dikenal dengan sebutan "Piil Pesenggiri". Dan setiap unsur dari piil pesenggiri ini terus diperkenalkan dan juga disosialisasikan kepada masyarakat Lampung untuk dipraktekkan dalam kehidupan sehari-harinya (Lintje Anna Marpaung, 2013, hlm. 124). Piil Pesenggiri ini sendiri merupakan kumpulan yang falsafah yang bersumber dari kitab-kitab yang dianut oleh 
masyarakat Lampung. Seperti yang dikatakan oleh Fachruddin dan Haryadi (1996) bahwa

Piil Pesenggiriadalah butir-butir falsafah yangbersumber dari kitab-kitab adat yang dianut dalam ulun lampung, antara lain yaitu kitab Kuntara Rajaniti,Cempala dan Keterem. Ajaran kitab-kitab tersebut diajarkan dari mulut ke mulut melalui penuturan para pemangku adat dari generasi ke generasi (hlm. 3)

Di dalam Piil Pesenggiri ini terdapat nilai dan norma yang mengatur tata hidup masyarakat Lampung sebagai makhluk sosial. Piil pesenggiri ini meliputi nilai-nilai luhur dan hakiki yang menunjukkan kepribadian serta jati diri dari masyarakat Lampung itu sendiri, karena nilainilai luhur yang ada di dalam falsafah hidup tersebut sesuai dengan kenyataan hidup masyarakat Lampung. Sebagaimana yang dijelaskan oleh Iskandar Syah (1999) bahwa

Piil pesenggiri secara harfiah berarti perbuatan atau perangai manusia yang agung dan luhur didalam nilai dan maknanya, oleh karena itu patut dipatuhi dan pantang untuk diingkari. Sedangkan dalam dokumen literature resmi, piil pesenggiri diartikan segala sesuatu yang menyangkut harga diri, prilaku dan sikap hidup yangharus menjaga dan menegakkan nama baik, martabat pribadi maupun kelompok. Secara totalitas piil pesenggiri mengandung makna berjiwa besar, mempunyai perasaan malu, rasa harga diri, ramah, suka bergaul, tolong-menolong dan bernama besar (hlm. 24-25)

Jadi Piil Pesenggiri ini merupakan wujud dari harga diri yang dimiliki oleh masyarakat Lampung. Masyarakat Lampung akan dikatakan memiliki harga diri apabila masyarakatnya sudah dapat melaksakan beberapa unsur yang ada didalamnya. Piil Pesenggiri sendiri terdiri dari beberapa unsur yaitu dari bejuluk adek yang merupakan pemberian gelar kehormatan apabila seseorang telah mencapai suatu pencapaian yang besar dalam hidupnya. Hal inilah yang mewajibkan masyarakat Lampung untuk tekun dan giat bekerja hingga berprestasi dan dapat berprestisedalam masyarakat. Selanjutnya ada Nemui nyimah yang berarti sopan santun dan keramahan masyarakat Lampung dalam menyambut tamu yang berkunjung kerumahnya. Termasuk pula rasa menghargai masyarakat pendatang yang banyak terdapat di daerah Lampung. Hal ini sejalan dengan apa yang dikatakan oleh Tubagus Ali Rachman (2017, hlm. 201) dalam jurnal ilmiahnya bahwa orang Lampung memiliki budaya yang sangat baik dalam menerima pendatang, karena pada hakekatnya masyarakat Lampung sangat cinta damai, toleran dan juga senang bergaul. Karena hal inilah jarang terjadi konflik seperti yang sudah disebutkan di atas. Lalu Nengah nyappur menggambarkan bahwa masyarakat Lampung memiliki sifat yang mudah bergaul, toleransi, dan mufakat atau senang bermusyawarah dalam mengambil keputusan, dan terakhir adalah sakai sambayan merupakan gambaran masyarakat lampung yang memiliki sifat gotong-royong atau tolong menolong.

Sebagai falsafah hidup masyarakat Lampung, Piil Pesenggiri ini harus diterapkan dalam kehidupan bermasyarakat oleh masyarakat Lampung dimana pun ia berada. Masyarakat Lampung harus menerapkan nilai-nilai yang terdapat dalam 4 aspek Piil Pesenggiri. Sebagai masyarakat Lampung yang memiliki "Piil", masyarakat Lampung harus bisa menjaga nama baiknya dengan tidak melakukan hal-hal yang dilarang oleh nilai dan norma yang berlaku dalam masyarakat, masyarakat Lampung harus mudah berbaur dengan lingkungan sekitarnya, harus menyambut tamu yang berkunjung dengan baik, dan ia harus memiliki sifat gotong-royong dan saling tolong menolong.

Tetapi pada kenyataannya, berdasarkan pengamatan yang dilakukan pada beberapa mahasiswa Lampung, ditemukan bahwa penerapan piil pesenggiri pada saat masyarakat Lampung merantau ke kota Bandung mengalami beberapa perubahan karena mereka mengalami hambatan. Penerapan piil pesenggiri menjadi tidak sempurna pada saat masyarakat Lampung berada di tanah rantau. Hal tersebut disebabkan karena kondisi masyarakatnya berbeda. Maka dari itulah, hal ini menjadi menarik untuk diteliti lebih lanjut.

\section{METODE PENELITIAN}

Penelitian ini dilakukan dengan menggunakan pendekatan kualitatif. Peneliti memilih menggunakan pendekatan kualitatif karena dalam meneliti tentang penerapan Piil Pesenggiri yang dilakukan oleh mahasiswa Lampung di tanah rantau tidak dapat diukur menggunakan alat-alat ukur yang dilakukan pada pendekatan kuantitatif. Apabila menggunakan pendekatan kualitatif, maka peneliti dapat mengamati kondisi yang terjadi dilapangan secara lebih mendalam dengan menggunakan beberapa teknik pengumpulan data yang akan membantu seperti misalnya wawancara pada informan yang akan dilakukan secara mendalam agar data yang didapatkan akan semakin akurat. Sedangkan untuk metode yang digunakan dalam penelitian ini adalah metode deskriptif. Dimana hasil dari penelitian yang telah akan disajikan dalam bentuk deskriptif. Hasil dari penelitian akan dijabarkan atau diuraikan dalam bentuk tulisan berdasarkan dari jawaban masalah yang akan angkat oleh peneliti. Agar didapatkan 
data yang akurat, maka dari itu peneliti memilih informan yang tepat yaitu mahasiswa asli yang berasal dari Lampung yang merupakan keturunan asli Suku Lampung dan juga dibesarkan oleh keluarganya di daerah Lampung. Peneliti memilih mahasiswa Lampung yang sedang menempuh pendidikan di 3 universitas Kota Bandung yang didalmnya terdapat paguyuban mahasiswa Lampung yang masih aktif yaitu UPI, ITB dan Universitas Telkom.

Peneliti menggunakan beberapa teknik pengumpulan data diantaranya dengan metode wawancara mendalam, observasi, dan dokumentasi. Selanjutnya peneliti menguji keabsahan data dengan cara triangulasi sumber data dan juga teknik pengumpulan data. Dan dalam penelitian ini aka menggunakan analisis data. Dimana data yang telah diperoleh dari lapangan akan dianalisis dan kemudian akan dilaporkan dalam bentuk tulisan. Tahap-tahap dalam analisis data tersebut adalah data reduction, data display, dan conclusion drawing/verification.

\section{HASIL DAN PEMBAHASAN 3.1. Cara Mahasiswa Lampung Menerapkan Piil Pesenggiri sebagai Falsafah Hidup di Tanah Rantau.}

Mahasiswa Lampung dapat menerapkan aspekaspek dalam piil pesenggiri dengan baik di lingkungan kampusnya. Tetapi, mahasiswa Lampung mengalami beberapa hambatan dalam menerapkan aspek-aspek dalam piil pesenggiri ini di lingkungan tempat tinggalnya selama berada di tanah rantau. Hal itu terjadi karena perbedaan kondisi sosial antara lingkungan tempat tinggalnya di tanah rantau dengan kondisi sosial di lingkungan kampusnya. Yang dimana hal tersebut berkaitan langsung dengan interaksi dan juga hubungan yang terjalin antara mahasiswa Lampung dengan masyarakat sekitar lingkungan tempat tinggalnya serta teman-teman di lingkungan kampusnya.

Kondisi sosial di lingkungan tempat tinggal mahasiswa Lampung selama berada di tanah rantau dapat tergambarkan dari beberapa hal berikut, diantaranya adalah tetangga yang ada disekitar tempat tinggal mahasiswa Lampung berasal dari berbagai macam suku dan didominasi oleh masyarakat dari Suku Sunda. Untuk tingkat ekonomi masyarakatnya berasal dari berbagai tingkat ekonomi, mulai dari yang menengah ke bawah sampai menengah ke atas. Masyarakatnya memiliki profesi yang beragam, mulai dari pedagang, pegawai, hingga pensiunan tentara. Tetapi masyarakat di lingkungan tempat tinggal mahasiswa Lampung ini, kebanyakan bekerja dari pagi hingga sore hari. Sedangkan di akhir pekan, mereka gunakan waktu mereka untuk beristirahat di rumah atau lebih memilih untuk menghabiskan waktunya dengan pergi bersama keluarganya. Karena waktu yang banyak dihabiskan di luar rumah inilah yang menyebabkan masyarakat di sekitar lingkungan tempat tinggal mahasiswa Lampung jarang untuk melakukan interaksi dengan masyarakat atau tetangga lainnya. Karena bagaimana bisa mereka melakukan interaksi apabila mereka jarang memiliki waktu dirumah. Seperti yang dikatakan oleh Siregar (2014, hlm. 36) bahwa interaksi sosial baru dapat terjadi apabila 2 orang bertemu, kemudian bertegur sapa, berjabat tangan dan juga saling menatap satu sama lain.

Interaksi sosial yang jarang terjadi ini juga menyebabkan banyak dari masyarakat di sekitar lingkungan tempat tinggal mahasiswa Lampung ini banyak yang saling tidak mengenal satu sama lain. Hal ini sejalan dengan yang dikatakan oleh Elly M. Setiadi \& Usman Kolip (2011, hlm. 862) bahwa dalam masyarakat perkotaan hubungan yang terjalin sangat kurang, bahkan banyak yang saling tidak mengenal antar anggota masyarakatnya. Dan biasanya pun, hubungan yang terjadi hanya sebatas apabila ada keperluan saja.

Waktu untuk berinteraksi pun sangat terbatas, hal ini dikarenakan kesibukan yang dimiliki oleh masing-masing masyarakatnya. Tidak hanya itu, interaksi yang jarang terjadi di antara masyarakat ini pun terjadi karena beberapa dari masyarakatnya cenderung bersifat individualis dan juga tertutup dengan lingkungan sekitarnya. Hal ini wajar apabila mengingat bahwa Bandung merupakan kota besar yang dimana masyarakatnya memiliki gaya hidup yang cenderung bersifat individualistik. Hal ini berkaitan dengan salah satu tipe masyarakat kota menurut Talcott Parsons, yaitu orientasi diri. Dimana masyarakat kota pada umumnya menjadikan tetangga bukan sebagai orang yang memiliki hubungan sosial bersifat kekeluargaan, karena masyarakat kota sudah terbiasa hidup tanpa menggantungkan diri dengan orang lain. Maka dari itulah masyarakat kota khususnya di tempat tinggal mahasiswa Lampung yang masih bagian dari kota, cenderung bersifat individualistik.

Interaksi sosial yang jarang terjadi ini berdampak langsung pada hubungan yang terjadi antara mahasiswa Lampung dengan masyarakat sekitar tempat tinggalnya tersebut, karena seperti apa yang dikatakan oleh Yogi Setiawan (2015, hlm.15) bahwa interaksi sosial yang terjadi akan menghasilkan pola hubungan yang baik pula. Karena, jarang terjadinya interaksi sosial antara mahasiswa Lampung dengan masyarakat sekitar tempat tinggalnya ini, menjadikan hubungan 
sosial antara mahasiswa Lampung dengan masyarakat sekitar tempat tinggalnya berjalan tidak begitu baik. Mereka hanya berjumpa sesekali saat mahasiswa Lampung akan pergi ke kampus atau pulang dari kampus, berbelanja di warung, ataupun ketika akan berangkat sholat ke masjid saat Sholat Jum'at.

Hal ini pula ditambahkan dengan jarang adanya kegiatan atau aktivitas sosial yang terjadi di lingkungan tempat tinggal mahasiswa Lampung selama berada di tanah rantau. Padahal apabila sering diadakan kegiatan bersama antara masyarakat di sekitar tempat tinggal mahasiswa Lampung tersebut akan menyebabkan seringnya masyarakat sekitar berinteraksi satu dengan yang lain. Dan dapat membuat hubungan yang ada menjadi semakin dekat terbangunnya rasa kekeluargaan. Seperti yang dikatakan oleh Soekanto (2008, hlm. 55) bahwa interaksi sosial merupakan salah satu syarat utama dari terjadinya sebuah aktivitas sosial. Yang dimana hal ini pula mengartikan bahwa apabila adanya sebuah aktivitas sosial atau kegiatan bersama yang dilaksakan rutin oleh masyarakat sekitar, maka hal tersebut akan menjadikan terciptanya sebuah hubungan masyarakat yang baik pula. Karena masyarakat akan sering menjalin interaksi dalam aktivitas atau kegiatan yang dilaksakan bersama tersebut.

Sementara, untuk kondisi sosial di lingkungam kampus mahasiswa Lampung selama berada di tanah rantau adalah teman-teman di lingkungan kampus mahasiswa Lampung berasal dari berbagai suku, yang didominasi oleh Suku Sunda dan juga Suku Jawa. Teman-teman di lingkungan kampus mahasiswa Lampung ini berasal dari berbagai latar belakang tingkat ekonomi, yang didominasi oleh teman-teman dari tingkat ekonomi menengah. Teman-teman mahasiswa Lampung selama berada di tanah rantau ini secara keseluruhan merupakan orangorang yang ramah dan terbuka, khususnya dengan mahasiswa Lampung yang merupakan mahasiswa rantauan. Perbedaan budaya yang ada justru membuat mahasiswa rantauan seperti mahasiswa Lampung ini menarik untuk dijadikan teman. Karena ketertarikan yang berasal dari perbedaan budaya atau suku inilah yang justru semakin membuat hubungan mahasiswa Lampung dengan teman-temannya semakin dekat. Hal ini dapat terjadi karena intensitas interaksi yang terjadi antara mahasiswa Lampung dengan temantemannya di kampus terjadi sangat sering. Bahkan di luar perkuliahan pun mereka sering berinteraksi dalam kegiatan organisasi jurusan bahkan hanya untuk sekedar berkumpul bersama untuk main atau untuk mengerjakan tugas.

Seringnya interaksi yang terjadi antara mahasiswa Lampung dengan teman-temannya di kampus ini, menjadikan hubungan yang terjalin antara mahasiswa Lampung dengan temantemannya menjadi cukup dekat. Mahasiswa Lampung pun dapat mudah berbaur dengan teman-teman kampusnya tersebut. Hal ini berkaitan dengan sifat atau perilaku yang dimiliki oleh orang atau masyarakat Lampung, seperti yang dikatakan oleh Hadikusuma (1989, hlm. 15) bahwa masyarakat Lampung mewarisi sifat atau pandangan hidup yang terdapat dalam piil piesenggiri yaitu salah satunya adalah aspek "nengah nyappur". Yang dimana aspek ini menggambarkan sifat dari masyarakat Lampung yang suka bergaul dan mudah untuk berbaur di lingkungannya dimana pun ia berada.

Karena masyarakat Lampung mudah bergaul dan terbuka terhadap siapa saja bahkan dengan teman yang berbeda suku sekali pun, selama berada di tanah rantau mereka memiliki sahabat yang kebanyakan berasal dari Suku Sunda ataupun Suku Jawa. Hal ini membuktikan bahwa masyarakat Lampung tidak hanya berteman dengan sesama masyarakat Lampung saja, tetapi juga dapat mudah berbaur dan menerima perbedaan dari suku lain selain Suku Lampung.

Jadi, dari penggambaran antara kondisi sosial di lingkungan tempat tinggal mahasiswa selama berada di tanah rantau dengan kondisi sosial di lingkungan kampus mahasiswa Lampung diatas memang terasa menjadi sedikit sulit bagi mahasiswa Lampung dalam menerapkan aspekaspek dalam piil pesenggiri ini. Khususnya untuk aspek nemui nyimah, nengah nyappur, dan juga sakai sambayan. Karena bagaimana bisa mahasiswa Lampung menyambut tamu dengan baik di tempat tinggalnya apabila jarang ada yang berkunjung, lalu berusaha berbaur apabila waktu untuk berinteraksi dengan masyarakat sekitar sangat jarang dan juga saling tolong-menolong apabila hubungan yang terjalin saja tidak terlalu dekat.

Penggambaran hubungan yang terjalin antara mahasiswa Lampung dengan masyarakat di Lingkungan tempat tinggalnya selama berada di tanah rantau dan teman-temannya di lingkungan kampusnya ini berkaitan langsung dengan proses adaptasi yang dilakukan oleh mahasiswa Lampung dengan lingkungannya selama ia berada di tanah rantau. Mahasiswa Lampung harus bisa beradaptasi dengan lingkungan barunya saat di tanah rantau dengan berbagi hambatan yang ada. Agar mahasiswa Lampung dapat terus mempertahankan nilai-nilai piil pesenggiri sebagai falsafah hidupnya selama berada di tanah rantau. Hal ini berkaitan dengan sebagaimana yang dikatakan oleh Talcot Parsons (Ritzer, 2012, hlm. 408) yang dikenal dengan sistem AGIL yang mengatakan bahwa bagian pertamanya yaitu Adaptation, dimana dalam tahap ini sebuah sitem 
harus bisa menyesuaikan diri dengan lingkungannya dengan segala hambatan atau keadaan yang ada. Sebuah sistem harus dapat bertahan pada situasi-situasi yang tidak mendukung sekalipun.

Maka dari itu, agar mahasiswa Lampung dapat bertahan selama tinggal di tanah rantau, ia harus dapat beradaptasi dengan berbagai keadaan yang dihadapinya selama berada di tanah rantau. Untuk adaptasi yang dilakukan oleh mahasiswa Lampung dengan lingkungannya selama ia berada di tanah rantau adalah melakukan adaptasi awal di daerah lingkungan tempat tinggal mahasiswa Lampung dan juga lingkungan kampus selama ia berada di tanah rantau adalah dengan cara memperkenalkan diri kepada Ketua RT setempat. Lalu untuk proses adaptasi yang selanjutnya seluruh informan ini berusaha untuk bertegur sapa dengan masyarakat sekitar tempat tinggalnya. Mereka juga berusaha untuk berkenalan dengan teman-teman di lingkungan kosan, bagi mereka yang tinggal dikosan. Lalu hal lain yang dilakukan untuk beradaptasi dan menyesuaikan diri dengan lingkungannya adalah dengan cara belajar memahami perbedaan kebudayaan dan juga kebiasaan yang ada pada masyarakat ataupun teman-temannya di tanah rantau. Hal ini dilakukan agar ia bisa lebih menghargai perbedaan yang ada dan dapat menyesuaikan sikap yang harus ia lakukan selama berada di tanah rantau. Karena mahasiswa Lampung merupakan masyarakat rantauan yang harus dapat menyesuaikan diri di tempat ia merantau. Seperti ada peribahasa yang mengatakan bahwa "Dimana bumi dipijak di sana langit dijunjung". Jadi sebagai masyarakat pendatang, mahasiswa Lampung sudah seharusnya harus menghargai kebudayaan dan kebiasaan masyarakat Sunda ataupun juga masyarakat yang bersuku lain selama ia berada di tanah rantau. Cara untuk beradaptasi lainnya yang dilakukan oleh mahasiswa Lampung adalah dengan cara memilih untuk bertanya dan juga belajar mengenai tipe masyarakat di Kota Bandung dan bagaimana sikap yang harus mereka ambil ketika menemukan kebiasaan yang berbeda dengan masyarakat yang ada di Kota Bandung yang terdiri dari berbagai tipe masyarakat.

Sementara untuk tahap kedua dari AGIL yaitu Goal Attainment yang dimana menurut Talcot Parsons (Ritzer, 2012, hlm. 408) bahwa tahap selanjutnya setelah menyesuaikan diri dengan lingkungannya, maka sistem harus memiliki sebuah tujuan yang jelas dan terarah agar dapat mencapai tujuan utamanya. Berkaitan dengan tujuannya disini adalah bagaimana cara agar mahasiswa Lampung dapat menerapkan falsafah hidup piil pesenggiri ini dengan baik selama ia merantau di Kota Bandung dengan berbagai hambatan yang dihadapinya selama berada di tanah rantau.

Maka dari itu, untuk mencapai tujuan utamanya tersebut, mahasiswa Lampung melakukan caracara sebagai berikut dalam kehidupannya selama ia berada di tanah rantau Kota Bandung. Untuk menerapkan aspek nemui nyimah di lingkungan sekitar tempat tinggal mahasiswa Lampung merasa sedikit sulit untuk dilakukan, karena memang tetangga di lingkungan sekitar mereka jarang untuk bertamu atau berkunjung ke rumah atau kosan mereka. Sedangkan untuk penerapan dengan teman di lingkungan kampus, biasanya mahasiswa Lampung ini menyambut atau menjamu teman-temannya yang main ke tempat tinggal mereka dengan bersikap ramah dan santun serta memberikan atau membelikan temantemannya makanan. Baik itu makanan kecil ataupun makanan berat. Apabila mereka tidak memiliki makanan di tempat tinggalnya, biasanya mahasiswa Lampung membelikan terlebih dahulu makanan untuk dijadikan cemilan ketika mengobrol. Untuk artian suka memberi dalam aspek nemui nyimah ini sendiri, mahasiswa Lampung sering membawakan teman-temannya oleh-oleh apabila mereka habis pulang ke Lampung. Mahasiswa Lampung juga merupakan teman yang suka memberi terutama memberi makanan.. Sikap sopan santun dan ramah tamah dalam menyambut tamu yang berkunjung serta kebiasaan memberi yang dilakukan oleh mahasiswa Lampung ini sejalan dengan yang dikatakan oleh Himyari Yusuf (2013, hlm. 129) bahwa masyarakat Lampung sangat membuka diri untuk menerima tamu yang berkunjung ke rumahnya, selain itu masyarakat Lampung juga suka memberi sesuatu dengan ikhlas sekaligus merupakan sebuah simbol ungkapan hati nurani dan ungkap keakraban.

Aspek yang selanjutnya dari piil pesenggiri ini adalah nengah-nyappur. Dalam menerapkan aspek ini di lingkungan tempat tinggalnya di tanah rantau, mahasiswa Lampung merasa sedikit kesulitan karena intensitas interaksi yang terjadi antara mahasiswa Lampung dengan masyarakat di sekitar tempat tinggalnya selama berada di tanah rantau tidak terlalu sering terjadi. Tetapi walaupun begitu, mahasiswa Lampung tetap berupaya untuk berbaur dengan masyarakat disekitarnya dengan melakukan beberapa cara seperti mengajak masyarakat untuk mengobrol apabila ada waktu-waktu tertentu mereka dipertemukan, seperti saat akan berangkat shalat jum'at ke masjid. Karena di saat akan berangkat Sholat Jum'at, mahasiswa Lampung merasa memiliki waktu yang sedikit lebih lama untuk berbincang dan mengobrol dengan masyarakat sekitar. Lalu untuk menerapkan aspek nengah nyappur ini di lingkungan teman kampus, 
mahasiswa Lampung selalu berusaha untuk berbaur dengan seluruh temannya baik di lingkungan akademik maupun organisasi tanpa membeda-bedakan suku, agama maupun golongan dari temannya tersebut.

Dan aspek terakhir adalah sakai sambayan. Untuk menerapkan aspek sakai sambayan di lingkungan masyarakat sekitar tempat tinggalnya di tanah rantau Kota Bandung,mahasiswa Lampung merasa cukup kesulitan karena hubungan yang terjalin antara mahasiswa Lampung dengan tetangganya atau masyarakat di sekitar lingkungan tempat tinggalnya tersebut terjalin tidak begitu erat. Jadi memang terbiasa untuk menyelesaikan urusannya masing-masing. Sedangkan untuk menerapkan aspek ini di lingkungan teman kampusnya, mahasiswa Lampung sering melakukan beberapa cara seperti membantu teman-temannya dalam hal akademik. Informan yang merupakan salah satu mahasiswa yang cukup cerdas dan unggul di perkuliahan, tidak segan dan ragu untuk membantu teman-temannya yang merasa kesulitan dalam masalah perkuliahan mereka. Mahasiswa Lampung bahkan tidak ragu untuk mengajari teman-temannya apabila ada materi mata kuliah yang temannya tidak paham.

Tidak hanya masalah kesulitan materi perkuliahan, mahasiswa Lampung juga sering membantu teman-temannya ketika kesulitan di akhir bulan melanda. Mahasiswa Lampung ini juga sering membantu teman-temannya yang tergabung dalam satu organisasi yang sama. Biasanya mahasiswa Lampung sering membantu temannya dengan mengurangin beban kerja temannya atau dengan kata lain membantu jobdesk temannya dalam organisasi yang mereka ikuti. Mahasiswa Lampung pun sering membantu temannya dalam hal jasa, seperti mengantar atau menjemput temannya yang membutuhkan bantuan. Dan yang terakhir, mahasiswa Lampung tidak sungkan untuk meminjamkan barang-barang yang sebenernya ia pun butuh dan memerlukannya, seperti misalnya alat transportasi yang setiap hari digunakan yaitu sepeda motor. Kebiasaan tolong menolong ini tidak terlepas dari aktivitas gotong-royong yang telah menjadi kebiasaan selama mahasiswa Lampung berada di daerahnya, hal ini sejalan dengan apa yang diungkapkan oleh Ayu Ariskha Mutiya (2015, hlm. 6) dalam skripsinya yang berjudul "Peranan Lembaga Adat dalam Melestarikan Nilai-Nilai Piil Pesenggiri di Desa Gunung Batin Udik Kecamatan Terusan Nunyai Kabupaten Lampung Tengah"bahwa masyarakat Lampung diharuskan suka untuk tolong menolong, bergotong royong dan juga saling memberi sesuatu yang diperlukan oleh sesama masyarakat. Tidak hanya terbatas pada hal materi saja, tetapi moril dan juga termasuk sumbangan saran serta pikiran.

\subsection{Faktor yang Menjadi Penghambat Mahasiswa Lampung dalam Menerapkan Pill Pesenggiri di Tanah Rantau}

Dalam menerapkan piil pesenggiri sebagai falsafah hidup masyarakat Lampung selama ia berada di tanah rantau, mahasiswa Lampung merasa mengalami hambatan. Hambatan tersebut berasal dari beberapa perbedaan yang dirasakan oleh mahasiswa Lampung mengenai perbedaan kondisi sosial masyarakat di Bandung dengan masyarakat yang ada di Lampung. Perbedaan yang paling terasa adalah perbedaan tipe masyarakat di Bandung dengan masyarkat yang ada di Lampung. Dimana masyarakat di kota-kota besar seperti Kota Bandun cenderung memiliki sifat individualistik. Sejalan dengan pemikiran Talcott Parsons dalam salah satu teorinya mengenai ciri-ciri masyarakat perkotaan yang dimana masyarakat kota memiliki sifat individualistik. Perbedaan dirasakan karena daerah tempat tinggal mahasiswa Lampung selama di Lampung bukan termasuk kota besar Yang dimana pada masyarakat di daerah Lampung di sore harinya masih terdapat ibu-ibu dan juga anak-anak yang masih sering berkumpul untuk mengobrol dan bermain di depan rumah mereka. Berbeda dengan masyarakat di Kota Bandung, masyarakatnya lebih banyak menghabiskan waktu di tempat kerja dan di dalam rumah mereka masing-masing. Sehingga jarang ada waktu untuk berkumpul dan menjalin hubungan silaturahmi dengan tetangga sekitar.

Perbedaan selanjutnya adalah mengenai perbedaan budaya yang ada pada masyarakat Lampung dan masyarakat di Kota Bandung Menurut mahasiswa Lampung, salah satu kebiasaan atau kebudayaan yang terasa berbeda dengan kebudayaannya di Lampung adalah adab dalam bertamu. Apabila di Lampung, sebagai tuan rumah masyarakat di Lampung dilarang dan tidak dianjurkan terlebih dahulu untuk memakan makanan yang disajikan, lain hal dengan kebiasaan pada masyarakat di daerah Bandung yang didominasi oleh Suku Sunda yang dimana kita sebagai tuan rumah harus terlebih dahulu mengambil makanan yang disajikan. Setelah tuan rumah mengambil makanan tersebut, barulah kemudian sang tamu akan ikut mengambil makanan yang telah disajikan oleh tuan rumah. Beberapa perbedaan budaya inilah yang mengharuskan mahasiswa Lampung untuk melakukan penyesuaian diri. Seperti yang dijelaskan oleh Siregar (2014, hlm. 53) bahwa 
"Penyesuaian diri merupakan faktor penting dalam kehidupan manusia". Hal ini pula dipertegas oleh Yogi Setiawan (2015, hlm.14) yang menyatakan bahwa perlu adanya adaptasi sosial dimana seorang individu harus melakukan penyesuaian kondisi dan perilaku dirinya sesuai dengan kondisi sosial dan juga budaya yang terdapat di lingkungannya, agar dapat menyesuaikan diri dengan baik dan mencapai tujuan utamanya.

Sedangkan untuk hambatan dalam menerapkan aspek-aspek yang ada di dalam piil pesenggiri ini sendiri, seperti yang sudah dipaparkan di pembahasan sebelumnya bahwa mahasiswa Lampung merasakan lebih sulit untuk menerapkannya di lingkungan tempat tinggal mereka dibandingkan dengan teman-teman di lingkungan kampusnya. Hal ini disebabkan karena interaksi yang sangat jarang terjadi antara mahasiswa Lampung dengan masyarakat sekitar lingkungan tempat tinggalnya. Inilah yang menjadikan mahasiswa Lampung kesulitan untuk membangun hubungan yang lebih erat dengan masyarakat sekitarnya. Maka dari itulah, terasa sulit untuk menerapkan aspek-aspek piil pesenggiri ini terutama pada aspek nemui nyimah, nengah nyappur dan juga sakai sambayan.

Terdapat beberapa faktor yang menjadi penghambat bagi mahasiswa Lampung dalam menerapkan piil pesenggiri selama berada di tanah rantau Kota Bandung. Faktor yang menjadi penghambat bagi mahasiswa Lampung dalam menerapkan piil pesenggiri terbagi menjadi 2, yaitu yang pertama adalah faktor internal yang berasal dari dalam diri mahasiswa Lampung itu sendiri. Faktor internal pertama yang menjadi penghambat adalah kurangnya rasa percaya diri yang dimiliki oleh mahasiswa Lampung saat harus berbaur dengan lingkungan barunya di tanah rantau. Kebudayaan dan kebiasaan yang berbeda menjadikan mahasiswa Lampung takut salah dalam bersikap dan berperilaku dengan lingkungan baru yang tentu saja memiliki standar perilaku yang terkadang berbeda dengan kebiasaan atau kebudayaan aslinya. Hal tersebut sejalan dengan yang dikatakan oleh Elly M. Setiadi \& Usman Kolip (2011, hlm. 567) bahwa terdapat salah satu prasangka tentang hubungan masyarakat dominan dan masyarakat minoritas yaitu adanya seuah perasaan dari dalam diri masyarakat minoritas bahwa adanya perasaan berbeda dari masyarakat dominan dan juga merasa sebagai orang yang asing. Jadi perasaan berbeda dengan masyarakat mayoritas yang ada di daerah tempat tinggalnya selama di tanah rantau ini yang terkadang menjadikan mahasiswa Lampung merasa bingung untuk memulai suatu pembahasan dalam obrolan.
Faktor internal selanjutnya adalah terbatasnya waktu yang dimiliki oleh mahasiswa Lampung untuk berhubungan atau melakukan interaksi dengan masyarakat di sekitar lingkungan tempat tinggalnya. Karena di hari-hari biasa, mahasiswa terlalu disibukkan dengan kegiatan perkuliahan yang kadang menghabiskana waktu hingga sore hari. Sementara di malam hari, biasanya mahasiswa Lampung sibuk dengan berbagai kegiatan organisasinya di kampus. Sementara waktu di akhir pekan mereka gunakan untuk mengerjakan tugas, ataupun digunakan untuk beristirahat dari padatnya kegiatan pada saat weekday. Dan terkadang, waktu yang bertabrakan dengan jadwal kegiatan yang diadakan oleh masyarakat seperti acara halbihalal saat hari raya pun menjadikan mahasiswa Lampung tidak dapat mengikuti acara-acara tersebut. Karena biasanya acara-acara tersebut diadakan di hari libur dan hari raya. Dimana pada saat hari raya ataupun hari libur lainnya, mahasiswa Lampung lebih memilih untuk pulang ke kampung halamannya masing-masing.

Sedangkan untuk faktor eksternal yang menjadi penghambat berasal dari kondisi masyarakat di sekitar tempat tinggal mahasiswa Lampung selama ia berada di tanah rantau. Faktor eksternal pertama yang menjadi penghambat bagi mahasiswa Lampung adalah jarang terjadinya interaksi yang terjadi antara mahasiswa Lampung dengan masyarakat sekitar tempat tinggalnya dikarenakan kesibukan masing-masing yang dimiliki oleh mahasiswa Lampung dan juga masyarakat di sekitar tinggalnya selama berada di tanah rantau. Kesibukan yang menyita waktu di hari-hari kerja, menjadikan masyarakat di sekitar lingkungannya memilih untuk menghabiskan waktu akhir pekannya di dalam rumah unutk berisistirahat atau menghabiskan waktunya dengan berjalan-jalan keluar rumah bersama keluarganya. Hal inilah yang menjadikan masyarakat sekitar tempat tinggalnya menjadi jarang untuk berbaur dan berinteraksi dengan masyarakat di sekitarnya. Tetapi di lain sisi, tidak sedikit pula masyarakatnya yang menutup diri mereka dan enggan untuk bersosialisasi terhadap tetangga di sekitarnya. Hal ini sejalan dengan apa yang diungkapkan oleh Elly M. Setiadi \& Usman Kolip (2011, hlm. 857) bahwa kehidupan masyarakat perkotaan sering pula dinilai sebagai masyarakat yang individual, bersifat heterogen dan memiliki kehidupan yang heterogen.

Menurut masyarakat asli yang sudah lama tinggal di daerah tempat tinggal mahasiswa Lampung tersebut pun mengatakan bahwa banyak masyarakat baru dan tinggal di daerah tersebut, yang enggan untuk menjalin silaturahmi dan juga berinteraksi dengan masyarakat sekitar. Keadaan seperti inilah yang menjadikan kesulitan bagi 
mahasiswa Lampung untuk membangun hubungan yang baik antara mahasiswa Lampung dengan masyarakat di sekitar tempat tinggalnya. Hal lain yang menjadi faktor eksternal dalam menerapkan aspek-aspek piil pesenggiri ini adalah berbedanya budaya atau kebiasaan. Seperti yang sudah dijelaskan sebelumnya bahwa perbedaan kebiasaan atau budaya yang ada pada masyarakat di tanah rantau adalah adab dalam bertamu. Adab bertamu dalam masyarakat Lampung, sebagai tuan rumah masyarakat Lampung dilarang dan tidak diperbolehkan untuk terlebih dahulu mengambil atau memakan makanan yang disajikan, lain hal dengan kebiasaan pada masyarakat di daerah Bandung yang didominasi oleh Suku Sunda, dimana sebagai tuan rumah mereka harus terlebih dahulu mengambil makanan yang disajikan. Setelah tuan rumah mengambil makanan tersebut, barulah kemudian sang tamu akan ikut mengambil makanan yang telah disajikan oleh tuan rumah. Hal inilah yang harus disesuaikan terlebih dahulu oleh mahasiswa Lampung terhadap perbedaan yang ada di kota rantau ketika ia menyambut tamu yang datang ke rumah atau kosan dan memiliki suku atau budaya yang berbeda.

Dan faktor terakhir yang menjadi penghambat bagi mahasiswa Lampung dalam menerapkan aspek-aspek piil pesenggiri adalah jarang adanya kegiatan yang dilaksanakan oleh masyarakat di lingkungan sekitarnya yang dapat menyatukan dan membuat hubungan antar masyarakatnya menjadi semakin erat. Kegiatankegiatan seperti gotong royong ataupun kumpulkumpul sudah mulai menghilang karena masyarakatnya yang sibuk dengan urusannya masing-masing. Ditambah pula dengan sering bergantinya tetangga sekitar karena perpindahan penduduk, menjadikan masyarakatnya saling tidak mengenal karena masyarakat baru yang tidak bersilaturahmi dengan masyarakat asli di daerah tersebut. Adapun kegiatan yang dilaksanakan pun hanya satu tahun sekali seperti misalnya halal-bihalal ataupun acara potong kurban. Yang dimana acara tersebut diadakan pada saat mahasiswa-mahasiswa Lampung sedang pulang ke kampung halamannya. Berbeda dengan masyarakat Lampung, seperti yang diungkapkan oleh Ayu Ariskha Mutiya (2015, hlm. 7) bahwa masyarakat Lampung sering mengadakan dan mengikuti kegiatan atau acara-acara yang diadakan oleh masyarakat sekitarnya, seperti acara-acara pernikahan yang dimana sebagai saudara atau pun tetangga masyarakat Lampung selalu ikut terlibat dalam acara tersebut untuk membantu sang tuan rumah yang mengadakan acara. Kontribusi dalam kegiatan seperti inilah yang menjadikan masyarakat Lampung menjadi solid, ketika ada tetangga atapun saudaranya yang melaksakan acara seperti ini pastilah tetangga atau saudara dan teman-temannya datang untuk membantu. Seperti yang dijelaskan oleh Tadjuddin Noer Effendi (2013, hlm. 5) bahwa gotong royong merupakan sebuah landasan falsafah Bangsa Indonesia, begitu juga yang berlaku dalam masyarakat Lampung ini. Sama halnya dengan yang diungkapkan oleh Dasrun Hidayat (2014, hlm. 93) bahwa masyarakat Lampung memiliki sifat yang suka tolong menolong atau bergotong-royong.

Berhubungan dengan adanya hambatan yang dirasakan oleh mahasiswa Lampung dalam menerapkan piil pesenggiri selama berada di tanah rantau, hal ini harus adanya integrasi dari peran eksternal selain mahasiswa Lampung sendiri yang turut berperan dalam membantu mahasiswa Lampung dalam mengimlementasikan aspek-aspek yang ada di dalam piil pesenggiri dan membantu mahasiswa Lampung dalam menghadapi serta mengatasi hambatan dalam menerapkan piil pesenggiri selama berada di tanah rantau. Seperti yang dijelaskan oleh Talcot Parsons (Ritzer, 2012, hlm. 408) bahwa dalam salah satu skema AGIL yaitu integration, yang menjelaskan bahwa harus adanya sebuah sistem yang mengatur hubungan antara bagian-bagian yang menjadi komponen. Hubungan tersebut pula berguna agar ketiga fungsi lainnya yaitu (A,G dan L) dapat terlaksana dengan baik. Komponenkomponen berikut ini adalah yang berperan membantu mahasiswa dalam menerapkan piil pesenggiri di tanah rantau yaitu terdiri dari teman, keluarga dan juga paguyuban mahasiswa Lampung yang terdapat pada masing-masing kampus mahasiswa Lampung tersebut.

Teman-teman mahasiswa Lampung selama berada di tanah rantau, berperan sebagai tempat bagi mahasiswa Lampung untuk belajar mengenai bagaimana cara beradaptasi kepada lingkungannya di tanah rantau, dan juga menjadi tempat bercerita serta tempat untuk meminta masukan atau solusi ketika mahasiswa Lampung mengalami kesulitan dalam beradaptasi dengan lingkungannya di tanah rantau dan juga dalam menerapkan piil pesenggiri di tanah rantau. Tidak berbeda jauh dengan peran dari lingkungan teman, keluarga pula memiliki peran sangat penting. Tidak berbeda jauh dengan peran dari teman mahasiswa Lampung, keluarga menjadi tempat bercerita dan juga tempat untuk meminta solusi bagi mahasiswa Lampung ketika ia harus beradaptasi dengan lingkungan yang baru dan menerapkan harus dapat menerapkan aspek-aspek piil pesenggiri ini di tengah-tengah lingkungannya yang baru.

Dan yang terakhir adalah peran dari paguyuban mahasiswa Lampung yang berada di masing-masing universitas tempat mahasiswa 
Lampung menempuh pendidikan di tanah rantau Kota Bandung. Peran dari paguyuban mahasiswa Lampung adalah paguyuban Lampung berperan sebagai media yang membantu mahasiswa Lampung agar dapat terus mampu menerapkan aspek-aspek yang ada di dalam piil pesenggiri ini selama ia berada di tanah rantau. Agar kebiasan menerapkan piil pesenggiri ini tidak begitu saja ditinggalkan dan dilupakan oleh mahasiswa Lampung meskipun ia sedang berada di tanah rantau. Proses penerapan aspek-aspek piil pesenggiri tersebut berada di dalam kegiatankegiatan yang diadakan oleh paguyuban tersebut. Mengapa acara-acara diadakan oleh paguyuban tersebut disebut sebagai media penerapan dari aspek-aspek piil pesenggiri, karena dalam proses pembuatan sampai dengan pelaksanaan acaranya mengandung aspek-aspek yang terdapat dalam piil pesenggiri seperti menjaga nama baik sebagai masyarakat Lampung dengan mengadakan kegiatan-kegiatan positif yang dapat membuat citra baik bagi masyarakat Lampung, lalu mereka berbaur dengan banyak teman baik teman baru maupun yang sudah dikenal sebelumnya, mengajarkan untuk saling memberi antar sesama dan juga kegiatan yang dilaksanakan tersebut dapat mengajarkan kita sebagai masyarakat untuk saling tolong-menolong sesama masyarakat dan membiasakan diri untuk bergotong-royong dalam menyelesaikan suatu hal.

\section{KESIMPULAN}

Mahasiswa Lampung dapat menerapkan aspek-aspek dalam piil pesenggiri dengan baik di lingkungan kampusnya. Tetapi, mahasiswa Lampung mengalami beberapa hambatan dalam menerapkan aspek-aspek dalam piil pesenggiri ini di lingkungan tempat tinggalnya selama berada di tanah rantau. Untuk cara mahasiswa Lampung dalam menerapkan piil pesenggiri selama mereka berada di tanah rantau adalah dengan cara berikut:

1.) Penerapan aspek nemui nyimah dilakukan dengan cara mahasiswa Lampung biasanya menyambut atau menjamu teman-temannya yang main ketempat tinggal mereka dengan bersikap ramah dan santun serta memberikan atau membelikan teman-temannya makanan. Baik itu makanan kecil ataupun makanan berat. Selain itu pula mahasiswa Lampung sering memberikan oleh-oleh kepada temannya apabila mereka pulang ke Lampung. Mahasiswa Lampung juga sering memberikan makanan apabila mereka memiliki makanan yang dibawa dari rumahnya.
2.) Penerapan aspek nengah nyappur dilakukan dengan cara mahasiswa Lampung berupaya untuk berbaur dengan masyarakat di sekitar tempat tinggalnya dengan cara mengajak ngobrol masyarakat apabila adawaktu-waktu tertentu mereka dipertemukan, seperti saat akan berangkat shalat jum'at ke masjid, mengajak anak-anak di sekitar tempat tinggalnya untuk main bersama ketika mereka ada waktu senggang, Lalu mahasiswa Lampung selalu berusaha untuk berbaur dengan seluruh temannya baik di lingkungan akademik maupun organisasi tanpa membeda-bedakan suku, agama maupun ras temannya.

3.) Penerapan aspek sakai sambayan dilakukan dengan cara membantu temantemannya dalam hal akademik, membantu temantemannya dalam kinerja di organisasi, membantu temannya yang kadang mengalami kesulitan ekonomi, membantu dalam hal jasa, seperti mengantar atau menjemput temannya yang membutuhkan bantuan, meminjamkan barang yang dibutuhkan oleh temannya seperti misalnya sepeda motor.

Sedangkan untuk yang menjadi penghambat bagi mahasiswa Lampung dalam menerapkan piil pesenggiri tersebut terbagi menjadi 2 macam yaitu faktor internal (kurangnya kepercayaan diri dari mahasiswa Lampung, terbatasnya waktu yang dimiliki oleh mahasiswa Lampung untuk berinteraksi dengan masyarakat sekitar) serta faktor eksternal (kondisi masyarakat yang cenderung individualis dan tertutup, perbedaan kebudayaan atau kebiasaan, jarang diadakannya kegiatan bersama di lingkungan tempat tinggal mahasiswa Lampung selama di tanah rantau).

Dan upaya yang dilakukan oleh mahasiswa Lampung untuk mengatasi hambatan yang dirasakan oleh mahasiswa Lampung dalam menerapkan piil pesenggiri selama berada di tanah rantau adalah dengan cara tetap menjaga sopan santun dengan masyarakat di lingkungan sekitar tempat tinggal mahasiswa Lampung selama berada di tanah rantau, dan juga berusaha untuk terus berbaur dengan masyarakat di lingkungan tempat tinggalnya selama ia berada di tanah rantau Kota Bandung.

\section{REFERENSI}

\section{Buku}

Facruddin, dan Haryadi. (1996). Falsafah Piil $\begin{array}{rrr}\text { Pesenggiri } & \text { Sebagai } & \text { Norma } \\ \text { Tatakrama } & \text { Kehidupan Sosial Masyarakat }\end{array}$ 
Lampung. Bandar Lampung: CV. Arian Jaya.

Hadikusama, H. (1989). Masyarakat dan AdatBudaya Lampung. Bandung: Mandar Maju.

Ritzer, G dan Gouglas J. Goodman. (2007). Teori Sosiologi Modern. Jakarta: Prenada Media Group.

Ritzer, G. (2012). Teori Sosiologi. Yogyakarta: Pustaka Pelajar.

Setiadi, Elly M \& Kolip Usman. Pengantar Sosiologi. (2011). Jakarta: Kencana.

Soekanto, Soerjono. (2008). Sosiologi Suatu Pengantar. Jakarta: Raja Grafindo Persada.

Syah, Iskandar. (1999). Sejarah Kebudayaan Lampung. Lampung:Universitas Lampung.

Yusuf, H. (2013). Filsafat Kebudayaan, Strategi Pengembangan Kebudayaan Berbasis Kearifan Lokal. Bandar Lampung: Harakindo Publishing.

\section{Skripsi dan Tesis}

Ariskha, A. (2016). Peranan Lembaga Adat Dalam Melestarikan Nilai-Nilai Piil Pesenggiri di Desa Gunung Batin Udik Kecamatan Terusan Nunyai Kabupaten Lampung Tengah. (Skripsi). Program Studi PPK FKIP, Universitas Lampung, Bandung.

Febriansyah, Yogi Setiawan. (2015). Pola Adaptasi Sosial Budaya Kehidupan Santri Pondok Pesantren Nurul Barokah). (Skripsi). Universitas Pendidikan Indonesia, Bandung.
Nurdiansyah, A. (2016). Nilai-Nilai Pendidikan Islam Berbasis Budaya Lokal Piil Pesenggiri di Masyarakat Desa Tanjung Agung Lampung Selatan. (Tesis). Pascasarjana, UIN Sunan Kalijaga Yogyakarta, Yogyakata.

Siregar, Anijar Hapni. (2014). Pola Asuh Keluarga Migran Asal Sumatera Utara. (Skripsi). Universitas Pendidikan Indonesia, Bandung.

Jurnal

Basri, Hasan. (2016). Kearifan Lokal Bisa Menyejukkan Lampung (Persprektif Komunikasi Lintas Budaya), 7 (1), 63-70.

Hidayat, D. (2014). Representasi Nemui-nyimah Sebagai Nilai-nilai Kearifan Lokal: Perspektif Public Relation Multikultur, 5 (1), 1-118.

Marpaung, L. Urgensi Kearifan Lokal Membentuk Karakter Bangsa dalam Rangka Pelaksanaan Otonomi Daerah, 2 (2), 120-131.

Noer, T. (2013). Budaya Gotong-Royong Masyarakat dalam Perubahan Sosial Saat Ini, 2 (1), 1-18.

Rachman, T. (2017). Pola Integrasi dalam Masyarakat Majemuk (Studi Ketahanan Sosial di Kecamatan Kotagajah, Lampung, 4 (2), 184-212.

Yusuf, H. (2016). Nilai-nilai dalam Falsafah Hidup Masyarakat Lampung, 10 (1), 167192. 